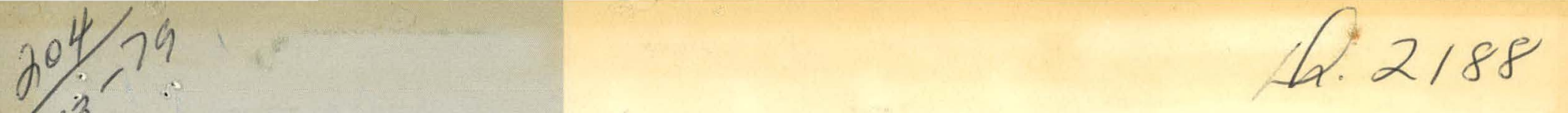

\title{
SURFACE ANALYSIS OF RESIDUAL CONTAMINANTS FROM DYE-PENETRANT TESTING
}

R. D. Seals

H. L. Richards

S. S. Cristy

O. P. Killeen

OAK RIDGE Y-12 PLANT OAK RIDGE, TENNESSEE prepared for the U.S. DEPARTMENT OF ENERGY under

U.S. GOVERNMENT Contract W-7405 eng 26 


\section{DISCLAIMER}

This report was prepared as an account of work sponsored by an agency of the United States Government. Neither the United States Government nor any agency Thereof, nor any of their employees, makes any warranty, express or implied, or assumes any legal liability or responsibility for the accuracy, completeness, or usefulness of any information, apparatus, product, or process disclosed, or represents that its use would not infringe privately owned rights. Reference herein to any specific commercial product, process, or service by trade name, trademark, manufacturer, or otherwise does not necessarily constitute or imply its endorsement, recommendation, or favoring by the United States Government or any agency thereof. The views and opinions of authors expressed herein do not necessarily state or reflect those of the United States Government or any agency thereof. 


\section{DISCLAIMER}

Portions of this document may be illegible in electronic image products. Images are produced from the best available original document. 
Reference to a company or product name does not imply approval or recommendation of the product by Union Carbide Corporation or the Department of Energy to the exclusion of others that may meet specifications.

Printed in the United States of America. Available from National Technical Information Service

U.S. Department of Commerce 5285 Port Royal Road, Springfield, Virginia 22161

Price: Printed Copy $\$ 4.00$; Microfiche $\$ 3.50$

This report was prepared as an account of work sponsored by an agency of the United States Government. Neither the United States Government nor any agency thereof, nor any of their employees, nor any of their contractors, subcontractors, or their employees, makes any warranty, express or implied, nor assumes any legal liability or responsibility for any third party's use or the results of such use of any information, apparatus, product or process disclosed in this report, nor represents that its use by such third party would not infringe privately owned rights. 
Date of Issue: January 30, 1979

Y-2164

Distribution Category: UC-25

\title{
SURFACE ANALYSIS OF RESIDUAL CONTAMINANTS \\ FROM DYE-PENETRANT TESTING
}

\author{
R. D. Seals \\ H. L. Richards \\ S. S. Cristy \\ O. P. Killeen \\ Instrumentation and Characterization Department \\ Y-12 Development Division
}

Oak Ridge Y-12 Plant

P. O. Box Y, Oak Ridge, Tennessee 37830

Prepared for the Department of Energy

Under US Government Contract W-7405-eng-26 


\begin{abstract}
Residual contamination on metal surfaces (U-0.75 Ti, aluminum, and steel) attributed to components from dye-penetrant testing was evaluated using ESCA and IMMA analyses. After the metal surfaces were dye-penetrant tested, there were either decreases or no detectable changes in all the elemental impurities except for small increases observed in carbon, silicon, chlorine, calcium, and/or iron on some of the metal surfaces. These contaminants were not increased to a level significantly greater than that presented by production contamination levels.
\end{abstract}




\section{CONTENTS}

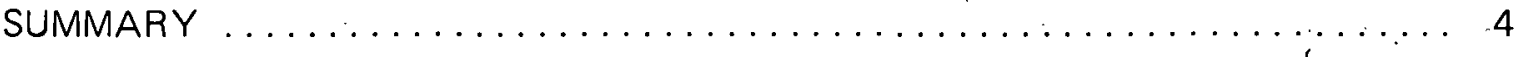

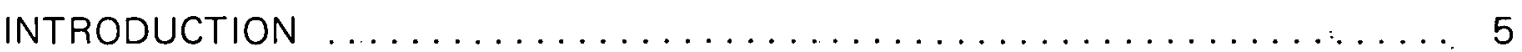

CONTAMINATION FROM DYE-PENETRANT TESTING $\ldots \ldots \ldots \ldots \ldots \ldots \ldots$

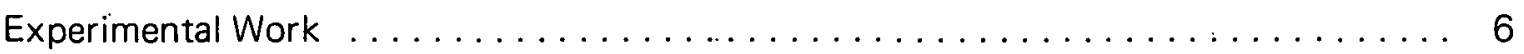

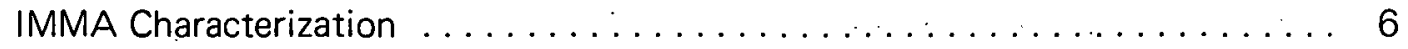

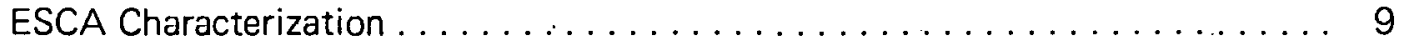

Conclusions ..................................... 10 


\section{SUMMARY}

Ion microprobe mass analysis (IMMA) and $X$-ray photoelectron spectroscopy [electron spectroscopy' for chemical analyses (ESCA)] were employed to ascertain the amount of residual contamination on metal surfaces (U-0.75 Ti, aluminum, and steel) resulting from the fluorescent-dye-penetrant testing procedure. Silicon and calcium were found to be the most probable contaminants left in increased abundance after dye-penetrant testing, and carbon was the next most probable impurity. In addition, increases in aluminum, chlorine, titanium, iron, and/or Mass $52\left(\mathrm{CaC}^{+}\right.$and/or $\left.\mathrm{Cr}^{+}\right)$were detected on some metal surfaces using IMMA. ESCA results revealed that the residual contamination levels were quite low (just above the detection limits). Results from both techniques show that the complete dye-penetrant testing procedure (inspection, final cleaning, and packaging) actually had a cleansing effect on all metals by the removal of surface contaminants and did not leave residual contamination levels significantly greater than those introduced by production. 


\section{INTRODUCTION}

Many of the metal parts produced in the Oak Ridge $Y-12$ Plant ${ }^{(a)}$ are subjected to a fluorescent-dye-penetrant test to assure that there is an absence of detrimental flaws. Freedom of the metal surfaces from residues resulting from components of the dye-penetrant test is necessary to meet a requirement that residuals from such tests do not introduce a threat of destructive incompatibility.

The fluorescent-dye-penetrant inspection procedure involves the following steps: (1) clean the part to be inspected with Magnaflux SKC-S cleaner (naphtha); (2) allow sufficient time for evaporation of all cleaner from the part; (3) apply the dye penetrant (Magnaflux ZL-30A) to the part by dipping; (4) allow the penetrant material to remain on the part for approximately 10 minutes (30 seconds for dipping and 9.5 minutes for drainage); (5) dip the part into the emulsifier (Magnaflux ZE-3) and keep the part immersed for approximately 2.5 minutes; (6) wash the part with water by using a pressure spray until the part looks clean when examined under black light; (7) transfer the cleaned part to a clean-part basket and dry the part in an oven at $135^{\circ} \mathrm{F}$ maximum for approximately 30 minutes; (8) after drying and cooling, apply developer (Magnaflux ZP-9) to the part by spraying, and (9) wait approximately three minutes and begin inspecting the part under black light.

Immediately after the fluorescent-dye-penetrant inspection procedure, the part should be cleaned and packaged to assure the removal and exclusion of surface contaminants that might promote stress-corrosion cracking according to the following procedure: (1) rinse the part freely with demineralized water to remove developer; (2) dry the part thoroughly by using lint-free paper wipes, and (3) place the dry part in a clean, dry polyethylene bag, partially heat seal the bag, and purge the bag with dry nitrogen for approximately two minutes.

All equipment and supplies that must be handled during cleaning and packaging must be maintained clean, and the part should be handled with rubber gloves during cleaning and with clean, white gloves (nylon, rayon, or cotton) at other times.

(a) Operated by the Union Carbide Corporation's Nuclear Division for the Department of Energy. 


\section{CONTAMINATION FROM DYE-PENETRANT TESTING}

\section{EXPERIMENTAL.WORK}

Aluminum (Types 1100-H14 and 5083-0), Type 316 stainless steel, and U-0.75 Ti coupons were employed in this investigation. Iron(III) chloride-etched $\mathrm{U}-0.75 \mathrm{Ti}$ coupons with surfaces containing cracks were studied and compared to the etched coupons without cracks. The original $\mathrm{U}-0.75 \mathrm{Ti}$ coupons and the $1100-\mathrm{H} 14$ aluminum, 5083-0 aluminum, and 316 stainless steel coupons were machined to simulate production surfaces. Additional U-0.75 Ti coupons which were not machined were studied to provide a surface with

Table 1

SAMPLE IDENTIFICATION AND SURFACE CONDITION

\begin{tabular}{lcl}
\hline \multicolumn{1}{c}{ Material } & $\begin{array}{c}\text { Sample } \\
\text { Number }\end{array}$ & \multicolumn{1}{c}{ Surface Conditions } \\
\hline U-0.75 Ti & 1 & Etched, not machined. \\
U-0.75 Ti & 2 & Etched, machined. \\
U-0.75 Ti & 3 & Etched, not machined, cracks. \\
U-0.75 Ti & 4 & Etched, machined, cracks. \\
$5083-0$ Aluminum & 5 & Machined. \\
$1100-$ H14 Aluminum & 6 & Machined. \\
316 Stainless Steel & 7 & Machined. \\
\hline
\end{tabular}
a greater potential for retaining contaminants. The samples studied and their surface condition are reported in Table 1 . The etched surface was removed on Samples 2 and 4 by machining. All machined samples were machined to a 32 finish. Surface morphologies of the U-0.75 Ti samples are shown in Figure 1. The coupon surfaces were cleaned initially by vapor degreasing and examined by using ESCA and IMMA techniques before and after the complete dye-penetrant-inspection, -final-cleaning, and packaging procedures. The results will be presented independently.

\section{IMMA Characterization}

Positive and negative secondary-ion spectra were obtained with the IMMA, using an $\mathrm{N}_{2}^{+}$ primary beam. Examination of the coupons revealed small amounts of carbon, fluorine, chlorine, sodium, magnesium, silicon, potassium, calcium, titanium, iron, and aluminum on the surfaces of the cleaned samples. In addition to these elemental impurities, detectable amounts of zinc and lead were found on the U-0.75 Ti coupon surfaces; sulfur on the 1100- $\mathrm{H} 14$ and 5083-0 aluminum surfaces; barium on 1100- $\mathrm{H} 14$ aluminum, 316 stainless steel, and U-0.75 Ti coupons; manganese on the 5083-0 aluminum, 316 stainless steel, and $\mathrm{U}-0.75 \mathrm{Ti}$ samples; molybdenum on the 316 stainless steel; and chromium, cobalt, and nickel on the U-0.75 Ti and 316 stainless steel specimens. After the samples were dye-penetrant tested, there were either decreases or no detectable changes in these elements listed except for the increases noted in Table 2. The values in the table represent abundances of the surface elemental impurities relative to those detected before dye-penetrant testing. $A$ table value less than 1.0 indicates a decrease; equal to 1.0 , no change; greater than 1.0 , an increase. Silicon and calcium were found to be the most probable contaminants left in increased abundance after dye-penetrant testing, with these elements increased on three of the four U-0.75 Ti specimens and four out of seven of all specimens. Carbon was the next most probable impurity with increases on three of the seven specimens. It should be noted that the Mass 52 increase in the $\mathrm{U}-0.75 \mathrm{Ti}$ specimens is primarily $\mathrm{CaC}^{+}$from calcium 


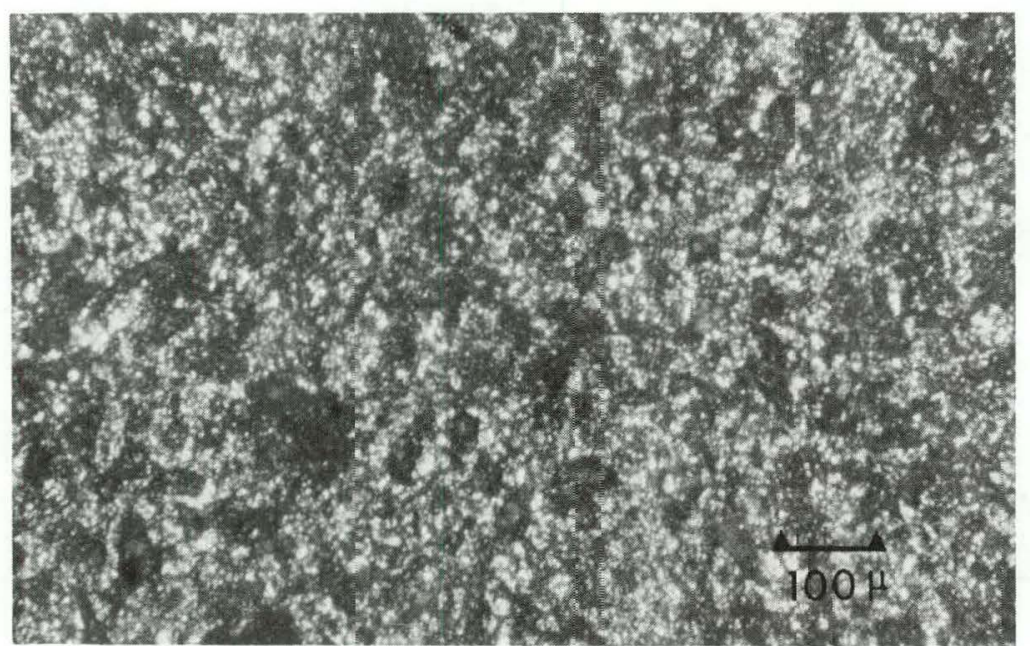

(a) Sample 1. (not machined)

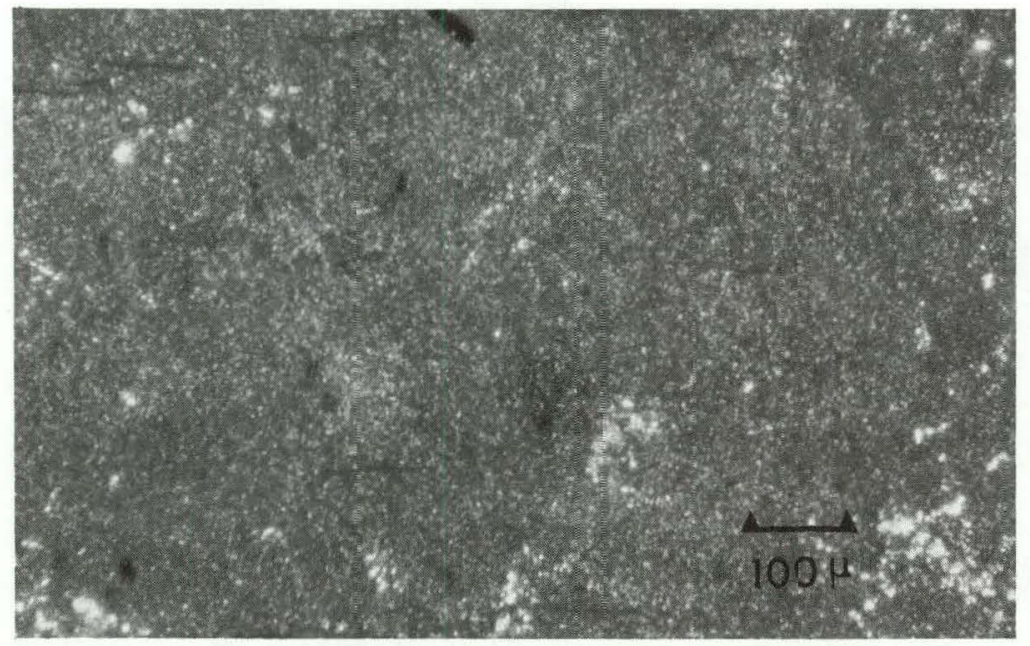

(c) Sample 3. (not machined; contains cracks)

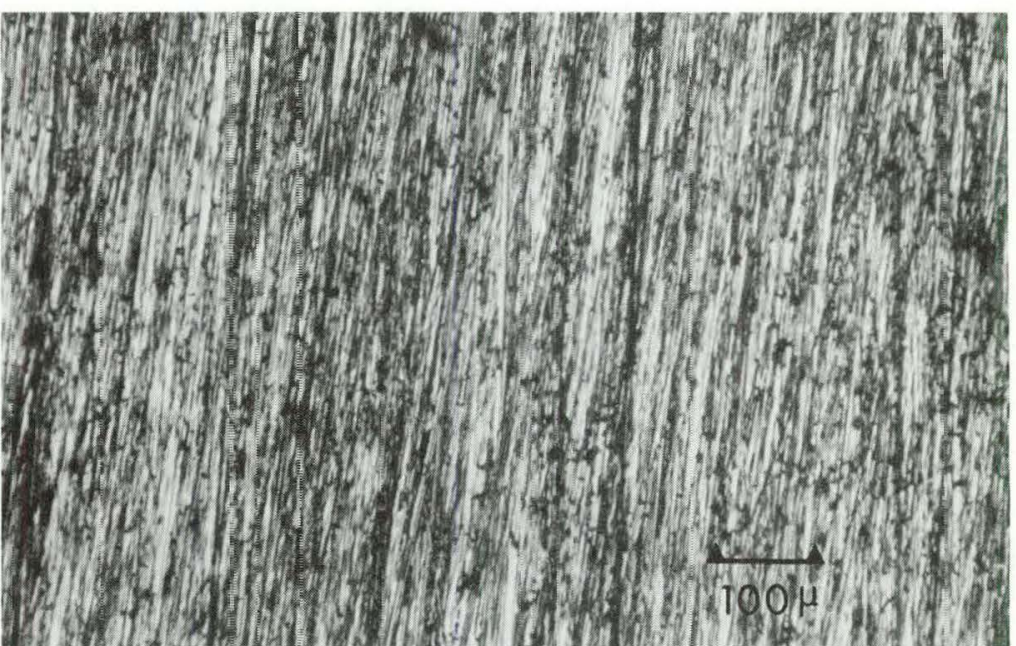

(b) Sample 2. (machined)

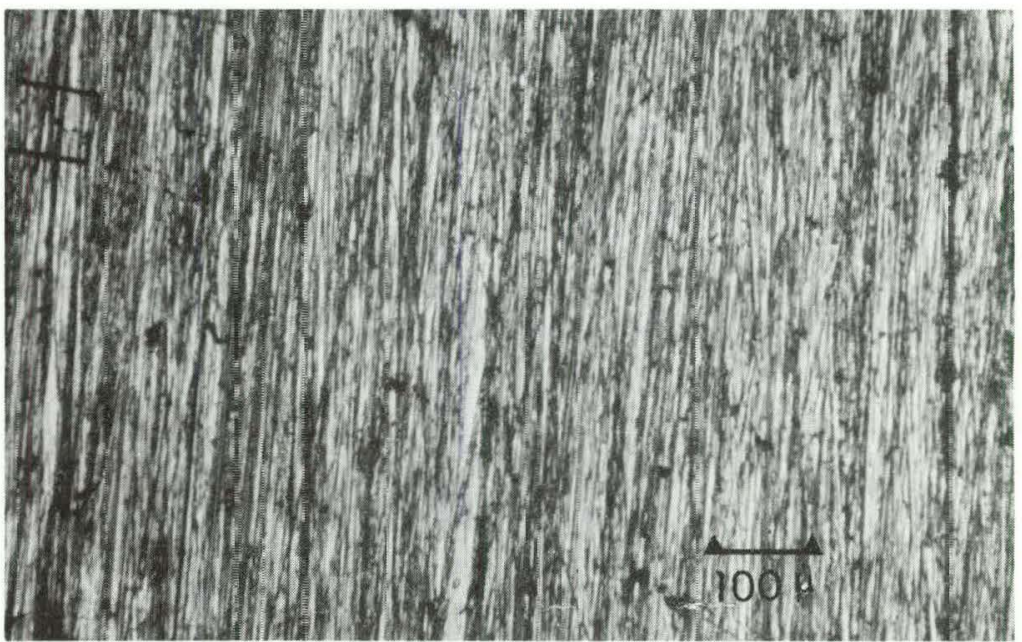

(d) Sample 4. (machined; contains cracks)

Figure 1. PHOTOMICROGRAPHS OF ETCHED URANIUM-0.75 TITANIUM SAMPLE SURFACES. 
Table 2

INFLUENCE OF THE DYE-PENETRANT TESTING PROCEDURE ON SURFACE IMPURITIES

\begin{tabular}{|c|c|c|c|c|c|c|c|c|c|c|c|c|c|}
\hline \multirow[b]{2}{*}{ Material } & \multirow{2}{*}{$\begin{array}{c}\text { Sample } \\
\text { Number(1) }\end{array}$} & \multicolumn{11}{|c|}{ Impurity (2) } & \multirow[b]{2}{*}{$\mathrm{m} / \mathrm{e}=52^{(3)}$} \\
\hline & & $\mathrm{C}$ & $F$ & $\mathrm{Na}$ & $\mathrm{Mg}$ & $\mathrm{Al}$ & $\mathrm{Si}$ & $\mathrm{Cl}$ & $\mathrm{K}$ & $\mathrm{Ca}$ & $\mathrm{Ti}$ & $\mathrm{Fe}$ & \\
\hline $\mathrm{U}-0.75 \mathrm{Ti}$ & 1 & 0.6 & 1.3 & 0.1 & 1.0 & 0.8 & $\underline{2.0}$ & 0.6 & 0.1 & 0.3 & $1.2^{(4)}$ & $\underline{1.5}$ & 0.6 \\
\hline $\mathrm{U}-0.75 \mathrm{Ti}$ & 2 & 3.2 & 1.0 & 0.1 & 0.6 & 0.4 & 0.9 & 4.7 & 0.1 & 1.6 & $0.6^{(4)}$ & 0.6 & 5.0 \\
\hline $\mathrm{U}-0.75 \mathrm{Ti}$ & 3 & 0.8 & 1.0 & 0.1 & 0.4 & 0.4 & 1.8 & 0.6 & 0.1 & 1.9 & $1.0^{(4)}$ & 0.6 & $\underline{5.1}$ \\
\hline $\mathrm{U}-0.75 \mathrm{Ti}$ & 4 & 0.5 & 0.4 & 0.7 & 0.6 & 0.3 & $\underline{2.1}$ & 0.9 & 0.9 & 4.9 & $\underline{1.5}^{(4)}$ & 1.3 & 4.8 \\
\hline Al (5083-0) & 5 & 1.9 & 1.0 & 0.4 & $0.9^{(4)}$ & $1.0^{(4)}$ & 0.5 & 0.7 & 0.2 & 2.0 & 1.0 & 1.0 & 1.0 \\
\hline Al (1100-H14) & 6 & 0.9 & 0.8 & 0.1 & 0.4 & $1.0^{(4)}$ & 0.5 & 1.3 & 0.1 & 0.2 & 0.8 & 0.7 & 1.0 \\
\hline 316 Stainless Steel & 7 & 1.7 & 0.9 & 0.9 & 1.4 & 1.9 & 1.6 & 1.0 & 1.0 & 0.6 & 3.1 & $1.0^{(4)}$ & $1.0^{(4)}$ \\
\hline Source $(5)$ & - & $D, E, P$ & $\mathrm{D}$ & $D, E$ & $D, P$ & $\overline{D, P}$ & $D, P$ & $D, E, P$ & $D, E, P$ & $D, P$ & $\mathrm{D}$ & $\mathrm{D}$ & $\mathrm{D}$ \\
\hline
\end{tabular}

(1) See text (Page 6) for a description of the sample numbers.

(2) Values represent abundances relative to that detected before dye-penetrant testing; ie, a 0.6 value in the table indicates a $40 \%$ decrease, a 1.4 value indicates a $40 \%$ increase, and 1.0 indicates no change. The underlined values indicate significant increases (values $\geqslant 1.5 ;$ a $50 \%$ increase)

(3) The major contributor to Mass 52 for Samples 1 through 4 is $\mathrm{CaC}^{+}$from calcium carbonate, while that for Samples 5 through 7 is chromium, $\mathrm{Cr}^{+}$.

(4) A major component of the alloy.

(5) Those components of the dye-penetrant test procedure that are sources of impurities are indicated as $D$ for developer, $E$ for emulsifier, and $P$ for dye penetrant. 
carbonate, although ${ }^{52} \mathrm{Cr}^{+}$also contributes to this peak. Although the detectable amounts of impurities on the rough surfaces (Samples 1 and 3, not machined) were larger than on the machined surfaces, the affinity of these surfaces to retain residuals from dye-penetrant testing was not greater. The complete dye-penetrant-inspection and final-cleaning procedures actually had a cleansing effect on all samples by the removal of surface contaminants. The source of the elemental impurities is given in Table 2. Spectrographic analyses of the chemicals used in the dye test indicate that the developer, which contains inorganic salts in addition to organic compounds, is the most likely source for the increase in the trace amounts of calcium, titanium, chlorine, carbon, chromium, aluminum, silicon, potassium, and iron. The dye penetrant and emulsifier are also sources of potassium, carbon, and chlorine. Silicon, calcium, and aluminum residues can also be attributed to the dye-penetrant material. Composition analyses of the developer, dye penetrant, and emulsifier revealed 460,84 , and $85 \mathrm{ppm}$ of chlorine, respectively, in these materials. The developer was found to contain $10 \%$ calcium, $3 \%$ silicon, $>3 \%$ titanium, $0.03 \%$ aluminum, and $>0.005 \%$ chromium.

\section{ESCA Characterization}

$X$-ray photoelectron spectroscopy was used to examine the surfaces of the aforementioned specimens both before and after dye-penetrant testing. Qualitative or wide-energy ESCA scans were made by using aluminum $K \alpha$ radiation at 250 watts $(12.5 \mathrm{kV}$ at $20 \mathrm{~mA})$. A qualitative comparison of the spectra was made to see if any contamination, as a result of the dye-penetrant test, remained on the surfaces.

It should be pointed out that ESCA is a surface method which probes the first few nanometers (tens of angstroms) of the surface. In terms of the amount of an element that can be detected in the surface layers of a solid sample, ESCA is a relatively insensitive technique compared to IMMA. The detection limits of ESCA for elements of interest are given in Table 3 . The values in Table 3 were calculated by using the elemental photoelectric cross sections and the ESCA detection limit for lead $\left(1 \mathrm{ng} / \mathrm{cm}^{2}\right)$, assuming that the elemental impurity was homogeneously distributed in the first $5 \mathrm{~nm}$ $(50 \AA)$ of the solid surface corresponding to an ESCA analysis volume of $5.81 \times 10^{-8} \mathrm{~cm}^{3}$. In all the investigations, the amount of surface contamination is quite low in terms of ESCA sensitivity where only a few species are observed, compared to the IMMA results. However, there were a few surface species that could be identified and showed some change as a result of the dye-penetrant test.

Table 3

ESCA DETECTION LIMITS

\begin{tabular}{ll}
\hline Element & $\begin{array}{c}\text { Detection Limit } \\
\text { (wt \%) }\end{array}$ \\
\hline $\mathrm{Al}$ & 0.3 \\
$\mathrm{C}$ & 0.2 \\
$\mathrm{Ca}$ & 0.07 \\
$\mathrm{Cl}$ & 0.1 \\
$\mathrm{Cr}$ & 0.03 \\
$\mathrm{~F}$ & 0.05 \\
$\mathrm{Fe}$ & 0.02 \\
$\mathrm{~K}$ & 0.08 \\
$\mathrm{Mg}$ & 0.02 \\
$\mathrm{Na}$ & 0.03 \\
$\mathrm{Si}$ & 0.2 \\
$\mathrm{Ti}$ & 0.04 \\
$\mathrm{U}$ & 0.008 \\
\hline
\end{tabular}

(1) Detection limits were calculated by assuming a homogeneous distribution of the elemental impurity in an ESCA analysis volume of $5.81 \times$ $10^{-8} \mathrm{~cm}^{3}$ and a depth of $5 \mathrm{~nm}$ $(50 \AA)$, see discussion in text (this page).

The etched U-0.75 Ti samples (Samples 1 and 3), which had rough surfaces, showed more overall contamination both before and after testing than the machined $U-0.75 \mathrm{Ti}$ surfaces, 
but some cleanup due to the dye-penetrant-test and final-cleaning procedures was observed. Contaminants peculiar to the etched specimens were iron, chlorine, lead, calcium, sodium, and sulfur. The machined $U-0.75 \mathrm{Ti}$ specimens (Samples 2 and 4) showed very little contamination, but a slight increase in calcium was observed on both after testing. An increase in silicon (probably silicate from the dye developer) was observed on all U-0.75 Ti specimens; however, this was low-level contamination.

The two aluminum samples (Samples 5 and 6 ) showed little contamination both before and after testing. Some chilorine and boron were present initially and were removed by the test. After the test, fluorine and silicon were present at low levels.

The stainless steel specimen (Sample 7) likewise showed a decrease in surface chlorine and an increase in silicon, but at levels just above the detection limit.

Following is a summary of the conclusions drawn from the ESCA data: (1) the contamination levels are quite low (just above the detection limit) both before and after testing; (2) chlorine is the largest surface contaminant before and calcium and silicon after dye-penetrant testing, and (3) particularly on the machined surfaces, the complete dye-penetrant procedure appears to have an overall cleaning effect on the metal surfaces.

\section{CONCLUSIONS}

Results of the IMMA and ESCA analyses, in combination, imply that the dye-penetrant-testing, final-cleaning, and protective-packaging operations, when "the procedures are closely followed, do not leave quantities of residual contaminants on the metal.surfaces that are significantly greater than those posed by production contamination levels, and actually cause a cleaning effect on the surfaces to remove contaminants: 


\section{Distribution}

Bendix - Kansas City

MacCurdy, G.

Department of Energy - Albuquerque

Meyer, H. N., Jr

Department of Energy - Oak Ridge

Hickman, H. D.

Leed, R. E.

Zachry, D. S., Jr

\section{Lawrence Livermore Laboratory}

Ernst, $K$

Inouye, W. S.

Nelson, W. E.

Technical Information Library

Los Alamos Scientific Laboratory

Hoyt, H. C.

Library Services

Oak Ridge Gaseous Diffusion Plant

Stief, S. S.

Wilcox, W. J., Jr

Oak Ridge National Laboratory

Weir, J. R., Jr

Oak Ridge Y-12 Plant

Armstrong, R. C.

Bailey, H. L.

Bernander, N. K.

Bostock, D. J.

Briscoe, O.W.

Burditt, R. B.

Cristy, S. S.

Cuddy, L. M.

Davis, R. L.

Dodson, W. H./Googin, J. M.

Fraser, R. J.
Jones, F. W.

Kahl, K. G.

Keith, A.

Killeen, O. P.

Kite, H. T.

Koger, J. W./Kollie, T. G.

Long, P. J./Nicely, J. W.

Marrow, G. B.

Mason, D. L.

McLendon, J. D.

Mills, J. M., Jr

Morrow, R.

Phillips, L. R.

Richards, N. L.

Riggs, C. R.

Seals, R. D.

Smith, H. F., Jr

Smith, R. D.

Smith, W. E.

Stoner, H. H./Butturini, W. G./Dritt, W. S.

Tewes, W. E./Montgomery, C. D.

Thompson, W. H., Jr

White, J. C.

Y-12 Central Files (master copy)

$Y-12$ Central Files (route copy)

$Y-12$ Central Files (Y-12RC)

$Y-12$ Contral Files (5)

Paducah Gaseous Diffusion Plant

Bewley, H. D.

Sandia - Albuquerque

Schwoebel, R. L.

Sandia - Livermore

Henry, K. W.

Union Carbide Corporation - New York

Tinsley, S. W.

University of Michigan

Stein, D. 